\title{
Pore forming channels as a drug delivery system for photodynamic therapy in cancer associated with nanoscintillators
}

\author{
Luiz Anastacio Alves ${ }^{1, *}$, Leonardo Braga Ferreira ${ }^{2, *}$, Paulo Furtado Pacheco ${ }^{3}$, Edith \\ Alejandra Carreño Mendivelso ${ }^{1}$, Pedro Celso Nogueira Teixeira ${ }^{1}$ and Robson Xavier \\ Faria $^{3}$ \\ 'Laboratório de Comunicação Celular, Instituto Oswaldo Cruz, Fundação Oswaldo Cruz-FIOCRUZ, 21045-900, Rio de Janeiro, \\ RJ, Brasil \\ ${ }^{2}$ Laboratório de Inflamação e Instituto Oswaldo Cruz, Fundação Oswaldo Cruz-FIOCRUZ, 21045-900, Rio de Janeiro, RJ, \\ Brasil \\ ${ }^{3}$ Laboratório de Toxoplasmose Instituto Oswaldo Cruz, Fundação Oswaldo Cruz-FIOCRUZ, 21045-900, Rio de Janeiro, RJ, \\ Brasil \\ "These authors contributed equally to this work
}

Correspondence to: Luiz Anastacio Alves, email: alveslaa@gmail.com

Keywords: drug delivery; cancer; PDT; nanoscintillators; pore forming channels

Received: August 16, $2017 \quad$ Accepted: March 27, $2018 \quad$ Published: May 18, 2018

Copyright: Alves et al. This is an open-access article distributed under the terms of the Creative Commons Attribution License 3.0 (CC BY 3.0), which permits unrestricted use, distribution, and reproduction in any medium, provided the original author and source are credited.

\section{ABSTRACT}

According to the World Health Organization (WHO), cancer is one of main causes of death worldwide, with 8.2 million people dying from this disease in 2012. Because of this, new forms of treatments or improvement of current treatments are crucial. In this regard, Photodynamic therapy (PDT) has been used to successfully treat cancers that can be easily accessed externally or by fibre-optic endoscopes, such as skin, bladder and esophagus cancers. In addition, this therapy can used alongside radiotherapy and chemotherapy in order to kill cancer cells. The main problem in implementing PDT is penetration of visible light deeper than $10 \mathrm{~mm}$ in tissues, due to scattering and absorption by tissue chromophores. Unfortunately, this excludes several internal organs affected by cancer. Another issue in this regard is the use of a selective cancer cell-photosensitizing compound. Nevertheless, several groups have recently developed scintillation nanoparticles, which can be stimulated by $\mathrm{X}$-rays, thereby making this a possible solution for light production in deeper tissues. Alternative approaches have also been developed, such as photosensitizer structure modifications and cell membrane permeabilizing agents. In this context, certain channels lead to transitory plasma membrane permeability changes, such as pannexin, connexin hemmichannels, TRPV1-4 and P2X7, which allow for the non-selective passage of molecules up to 1,000 Da. Herein, we discuss the particular case of the $\mathbf{P} 2 X 7$ receptor-associated pore as a drug delivery system for hydrophilic substances to be applied in PDT, which could also be carried out with other channels. Methylene blue (MB) is a low cost dye used as a prototype photosensitizer, approved for clinical use in several other clinical conditions, as well as photodynamic therapy for fungi infections.

\section{INTRODUCTION}

Photodynamic action: a brief history of cancer treatment

In the western World, the term photodynamic action, a literal translation of the German word "Wirkung der photodynamischen", was coined by von Tappeiner and collaborators to differentiate photodynamic action from the sensitization that occurs in photography films $[1,2]$. At the time, Von Tappeiner's group was investigating the effect of antimalarial drugs on certain protozoa. A $\mathrm{PhD}$ student, Raab, discovered that certain dyes, such as Acridine, display phototoxic effects on Paramaecium caudatum only when exposed to sunlight $[3,4]$. This was observed by chance, with controversial results, since the 
effects apparently depended on the sunlight conditions of their Laboratory at the Munich University. It is relevant to point out that Marcacci had recognized the phototoxicity of quinine on oocytes [5], but this seems to have been unknown by Von Tappeiner's team at the time.

Von Tappeiner quickly recognized the clinical potential of Raab's data, since he was apparently familiar with the work of a French neurologist that attempted to apply eosin to treat epilepsy, causing photoxicity skin effects [6]. Possibly based on that study, and on their own data, Von Tappeiner, H., and Jesionek, A. treated three patients presenting skin cancer and other pathologies with Photodynamic Therapy (PDT) [7]. In 1905, they treated more five patients presenting skin cancer, with good results [8]. The use of PDT to treat in vivo tumors was little explored until 1972, when Diamond and co-workers demonstrated a small decrease in tumors derived from a glioma cell line implanted in rats exposed to light and treated with haematoporphyrin [9]. In 1975, a breakthrough study was published on eleven human bladder carcinomas xenografted to artificially immunosuppressed mice treated with PDT, that demonstrated remarkable damage to the tumors [10]. Since then, PDT has been used to treat several cancer types easily exposed to light sources [11]. Most are skin cancers or tumors easily accessed by endoscopy devices. The largest obstacle for PDT application is the light necessary to reach deep into the cancer tissues.

\section{General photodynamic therapy aspects}

PDT has emerged as a promising alternative or as a possible combination to conventional treatments, such as surgery, chemotherapy and radiotherapy [12]. It is based on the use of a systemically or locally administrated photosensitive molecule. Once "excited" by light at an appropriate wavelength, the photosensitive molecule undergoes electronic transitions to higher energy states, making it reactive to several compounds in the surrounding environment [13-18]. Photosensitizers, as these photosensitive molecules are known, are excited in the presence of light. In the presence of molecular oxygen, this process, leads to a series of photochemical reactions that culminate in the generation of free radicals and singlet oxygens (highly reactive chemical species derived from molecular oxygen). These photochemical reactions cause oxidative damage and target cell death [13, 14]. The existence of modern laboratory apparatuses and fiber-optic endoscopy systems allow for light application at the appropriate wavelength in several parts of the body, permitting PDT application to internal tumors [19]. Figure 1 illustrates photodynamic therapy principles.

PDT efficiency depends on a high number of physicochemical and physiological properties, such as type of photosensitizer, drug concentrations, location of the photosensitizer in the tumor, adequate dosimetry (total light dose, exposure time and form of light exposure) and oxygen availability [16, 17]. PDT success requires specific conditions aiming at the high production of singlet oxygen, since numerous studies have demonstrated that this chemical species is the primary responsible for PDT cytotoxic effects $[15,20,21]$. Tissue light penetration is dependent on tissue characteristics and wavelength. Wavelengths in the red or infrared range are recommended for clinical application, since they exhibit greater tissue penetration within a "therapeutic window", from $600 \mathrm{~nm}$ to $800 \mathrm{~nm}$, which produces enough energy to support the formation of singlet oxygen species [15, 18]. To overcome this light penetration problem, Chen et al., 2006 [22] proposed the use of synthesized nanoparticles (nanoscintillators), which can absorb X-rays and generate visible light.

\section{Nanoscintillators}

Scintillation is the capability that certain substances present to emit light, triggered by interactions with ionizing radiation. Nanoparticles, as the name suggests, range from 10 to $1000 \mathrm{~nm}$, although in terms of biological significance, the range from 10 to $100 \mathrm{~nm}$ is the most applied [23]. Nanoscintillators are composed of inorganic salts, most doped with rare earth metals as depicted in Table 1.

The great advantage of nanoscintillators is the possibility of applying low energy X-rays $(300 \mathrm{KeV})$ to generate light, thus diminishing radiotherapy side effects or allowing for combined use with chemotherapy. Radiotherapy normally applied energies ranging from 6 to $20 \mathrm{MeV}$. X-rays show great penetration capacity, reaching regions inaccessible to visible light, such as the brain or deep regions in tumors (more than $5 \mathrm{~mm}$ ).

\section{Photodynamic therapy clinical applications}

PDT is a promising alternative for the treatment of infectious diseases and infected blood and derivatives, as well as for the photoinactivation of multiresistant strains or microbial biofilms [24-26] (see Table 2). In comparison to the usual cancer treatment procedures (radiotherapy, chemotherapy and surgery), PDT displays a number of advantages. It is non-invasive and can be applied to virtually all types of cancer. For example, Temoporfin Foscan ${ }^{\circledR}$ (a first generation photosensitizer), was applied for the treatment of lung, gastric, prostate and skin cancers [27]. PDT may also be used repeatedly without producing side effects, usually showing excellent healing results [28]. In addition, tissue preservation leads to practically no fibrosis, thereby conserving the functional anatomy and mechanical integrity of the organs undergoing the procedure, as well as selective tumor removal without secondary detrimental effect on surrounding healthy tissues [29]. PDT can also be used before or after aforementioned conventional treatments 
Table 1: Use of $\mathrm{X}$ - rays with nanoscintillators in different biological models

\begin{tabular}{|c|c|c|c|c|c|c|c|}
\hline Year & Nanoparticle & Size & $\begin{array}{l}\text { Nanoparticle } \\
\text { concentration }\end{array}$ & Photosensitizer & $\begin{array}{l}X \text {-rays } \\
\text { energy }\end{array}$ & $\begin{array}{c}\text { Biological } \\
\text { Model }\end{array}$ & References \\
\hline 2008 & $\mathrm{LaF}_{3}: \mathrm{Tb}^{3+}$ & $15 \mathrm{~nm}$ & $0.035 \mathrm{M}$ & $\begin{array}{l}\text { Meso-tetra (4-carboxyphenyl) } \\
\text { porphine (MTCP) }\end{array}$ & $120 \mathrm{keV}$ & N/A & Liu YF, et al. [88] \\
\hline 2010 & $\begin{array}{l}\mathrm{ZnO} \text { nanorods } \\
\text { (NRs) }\end{array}$ & $0.5 \mu \mathrm{m}$ & N/A & $\begin{array}{c}\text { P rotoporphyrin dimethyl } \\
\text { ester (PPDME) }\end{array}$ & N/A & T47D cells & Kishwar S, et al. [89] \\
\hline 2011 & $\mathrm{Y}_{2} \mathrm{O}_{3}$ & $12 \mathrm{~nm}$ & $2.5-95 \mu \mathrm{g} / \mathrm{mL}$ & Psoralen & $\begin{array}{l}2 \mathrm{~Gy}, 160 \text { or } \\
320 \mathrm{kVp}\end{array}$ & PC3 cells & Scaffidi JP, et al. [90] \\
\hline 2011 & $\mathrm{Gd}_{2} \mathrm{O}_{2} \mathrm{~S}: \mathrm{Tb}$ & $20 \mu \mathrm{m}$ & $5 \mathrm{mg} / \mathrm{mL}$ & Photofrin II & $\begin{array}{c}120 \mathrm{keV}, 20 \\
\mathrm{mAs}\end{array}$ & $\begin{array}{c}\text { Human } \\
\text { glioblastoma } \\
\text { cells }\end{array}$ & Abliz E, et al. [91] \\
\hline 2013 & $\mathrm{~Tb}_{2} \mathrm{O}_{3}$ & $10 \mathrm{~nm}$ & $1 \mathrm{mM}$ & Porphyrin & N/A & N/A & Bulin AL, et al. [92] \\
\hline 2013 & $\mathrm{ZnO}$ & $50 \mathrm{~nm}$ & $0.3-0.6 \mu \mathrm{M}$ & $\begin{array}{c}\text { meso-tetra } \\
\text { (4-sulfonatophenyl) porphyrin } \\
\text { (TSPP) }\end{array}$ & N/A & $\begin{array}{l}\text { Escherichia } \\
\text { coli }\end{array}$ & Senthilkumar S, et al. [93] \\
\hline 2014 & $\mathrm{LaF}_{3}: \mathrm{Ce}^{3+}$ & $2 \mu \mathrm{m}$ & $1 \mu \mathrm{g} / \mathrm{mL}$ & Protoporphyrin IX (PPIX) & $3 \mathrm{~Gy}$ & PC3 cells & Zou X, et al. [94] \\
\hline 2016 & $\underset{\mathrm{Dy}^{3+}}{\mathrm{Sr}_{2} \mathrm{MgSi}_{2} \mathrm{O}_{7}: \mathrm{Eu}^{2+}}$ & $273 \mathrm{~nm}$ & $10 \mu \mathrm{g} / \mathrm{mL}$ & Protoporphyrin IX (PPIX) & 1-7 Gy & $\mathrm{PC} 3$ & Homayoni $\mathrm{H}$, et al. [95] \\
\hline 2014 & $\mathrm{Cu}-\mathrm{Cy}$ & $\begin{array}{c}50-100 \\
\mathrm{~nm}\end{array}$ & $50 \mu \mathrm{g}$ & Self & 5 Gy & $\begin{array}{c}\text { MCF-7 } \\
\text { xenograft }\end{array}$ & L Ma, et al. [96] \\
\hline 2016 & $\mathrm{ZnS}: \mathrm{Cu}, \mathrm{Co}$ & $4 \mathrm{~nm}$ & $0.05 \mathrm{mM}$ & $\begin{array}{l}\text { Tetrabromorhodamine- } 123 \\
\text { (TBrRh123) }\end{array}$ & 2 Gy & PC3 cells & L Ma, et al. [97] \\
\hline 2015 & $\mathrm{SrAl}_{2} \mathrm{O}_{4}: \mathrm{Eu}^{2+}$ & $80 \mathrm{~nm}$ & $50 \mu \mathrm{g} / \mathrm{mL}$ & Merocyanine 540 (MC540) & $0.5 \mathrm{~Gy}$ & $\begin{array}{c}\text { U87MG } \\
\text { xenograft }\end{array}$ & Chen $\mathrm{H}$, et al. [98] \\
\hline 2015 & $\mathrm{LaF}_{3}: \mathrm{Tb}$ & $3-45 \mathrm{~nm}$ & N/A & Rose Bengal (RB) & $2-10 \mathrm{keV}$ & $\mathrm{N} / \mathrm{A}$ & Tang Y, et al. [99] \\
\hline 2015 & $\mathrm{LaF}_{3}: \mathrm{Tb}$ & $3-45 \mathrm{~nm}$ & $20 \mathrm{mg} / \mathrm{mL}$ & Rose Bengal (RB) & N/A & Tumor model & $\begin{array}{l}\text { Elmenoufy AH, } \\
\text { et al. }[100]\end{array}$ \\
\hline 2016 & $\mathrm{CeF}_{3}$ & $7-11 \mathrm{~nm}$ & $0.1-0.9 \mu \mathrm{M}$ & Veterporfin (VP) & $\begin{array}{l}6 \mathrm{~Gy}, 8 \mathrm{keV} \\
\text { or } 6 \mathrm{MeV}\end{array}$ & Panc-1 & Clement S, et al. [101] \\
\hline 2015 & LiYF4:Ce ${ }^{3+}$ & $34 \mathrm{~nm}$ & $25-50 \mu \mathrm{g} / \mathrm{mL}$ & $\mathrm{ZnO}$ & 8 Gy & HeLa cells & Zhang C, et al. [102] \\
\hline 2015 & $\mathrm{SiC} / \mathrm{SiOx} \mathrm{NWs}$ & $20 \mathrm{~nm}$ & $50 \mu \mathrm{g} / \mathrm{mL}$ & Porphyrin & 2 Gy, 6 MV & A549 cells & Rossi F, et al. [103] \\
\hline 2015 & $\mathrm{ZnO} / \mathrm{SiO}_{3}$ & $98 \mathrm{~nm}$ & $0.005-0.05 \mathrm{M}$ & $\mathrm{ZnO}$ & $\begin{array}{l}200 \mathrm{kVp}, \\
2 \mathrm{~Gy}\end{array}$ & $\begin{array}{l}\mathrm{LNCaP} \text { and } \\
\mathrm{Du} 145 \text { cells }\end{array}$ & Generalov R, et al. [104] \\
\hline 2015 & $\mathrm{GdEuC}_{12}$ micelle & $4.6 \mathrm{~nm}$ & $500 \mu \mathrm{M}$ & Hypericin (Hyp) & $5-40 \mathrm{KeV}$ & HeLa cells & Kascakova S, et al. [105] \\
\hline
\end{tabular}

$\mathrm{N} / \mathrm{A}=$ Not applicable.

without compromising these therapeutic modalities. In addition, due to the inactivation of the photosensitizer in the absence of light, PTD shows low systemic toxicity. Finally, many PDT procedures can be performed in an ambulatory environment, lowering costs and making the procedure more acceptable to patients, resulting in increased patient adherence to treatment $[28,30,31]$.

\section{Photosensitizers}

Photosensitizing (PS) agents are essential PDT components. They are responsible for transferring the energy required for the occurrence of photochemical reactions that result in selective cell or tissue destruction [32]. A wide range of natural and synthetic compounds are capable of absorbing radiation in the UV-visible spectrum and generating singlet oxygen species, such as plant-derived products and synthetic macrocyclic complexes [14]. To function as a photosensitizer, a molecule must exhibit the following properties: (1) a high absorption coefficient in the spectral region of the excitation light source; (2) an appropriate triplet energy state $\left(\mathrm{E}_{\mathrm{T}} \geq 95 \mathrm{~kJ} \cdot \mathrm{mol}^{-1}\right)$, in order to transfer to molecular oxygen in the ground state; (3) a high quantum triplet yield $\left(\varphi_{\mathrm{T}} \geq 0.4\right)$, long triplet half-life state $\left(\tau_{\mathrm{T}} \geq 1 \mu \mathrm{s}\right)$ and (4) a high photostability state [33].

Over 1450 molecules with potential PDT applications have been catalogued [34]. However, only some may be applied for this purpose, since the costs for their introduction into the clinical practice related to clinical tests are quite high. Thus, only sensitizers with "exceptional" properties justify the financial expenditure [34]. In addition to suitable chemical and physical properties, other characteristics are recommended for a drug to be considered optimal for PDT, including high chemical purity and rigorous and simple chemical synthesis; preferential accumulation at the site of interest; lack of toxicity in the dark; strong phototoxicity; rapid clearance from normal tissues; amphiphilicity; easy administration by various routes; low manufacturing cost and easy storage and marketing $[15,35,36]$. 
Table 2: Use of MB in different PDT

\begin{tabular}{|c|c|c|c|c|c|c|c|}
\hline Year & $\begin{array}{l}\text { Patient } \\
\text { number }\end{array}$ & MB concentration & Administration & Indication & $\begin{array}{l}\text { Light } \\
\text { Energy }\end{array}$ & $\begin{array}{l}\text { Wavelength } \\
\text { light source }\end{array}$ & References \\
\hline 2005 & 60 & $\begin{array}{l}2 \% \text { dissolved in } \\
\text { acetone }\end{array}$ & Injection & Onychomycosis & $18 \mathrm{~J} / \mathrm{cm}^{2}$ & 600 to $750 \mathrm{~nm}$ & Tardivo JP, et al. [46] \\
\hline 2005 & 10 & $\begin{array}{l}2 \% \text { aqueous } \\
\text { solution }\end{array}$ & Intratumor injection & $\begin{array}{l}\text { Metastatic melanoma, } \\
\text { Basal cell carcinoma, } \\
\text { Squamous cell, Breast } \\
\text { cancer, Kaposi's } \\
\text { sarcoma. }\end{array}$ & $\begin{array}{c}18 \text { to } 36 \mathrm{~J} / \\
\mathrm{cm}^{2}\end{array}$ & 600 to $750 \mathrm{~nm}$ & Tardivo JP, et al. $[46,85]$ \\
\hline 2015 & 20 & $\begin{array}{c}2 \% \text { aqueous } \\
\text { solution and } 0,2 \% \\
\text { hydrogel }\end{array}$ & $\begin{array}{l}\text { Intralesional } \\
\text { injection and } \\
\text { topically }\end{array}$ & $\begin{array}{l}\text { Nodular or ulcerative } \\
\text { basal cell carcinoma }\end{array}$ & $48 \mathrm{~J} / \mathrm{cm}^{2}$ & N.I & Samy NA, et al. [106] \\
\hline 1997 & 3 & $10 \%$ & Topically & $\begin{array}{l}\text { chronic plaque-stage } \\
\text { psoriasis }\end{array}$ & $5 \mathrm{~J} / \mathrm{cm}^{2}$ & 600 to $700 \mathrm{~nm}$ & Schick E, et al. [107] \\
\hline 2006 & 26 & $\begin{array}{l}5 \% \text { aqueous } \\
\text { solution }\end{array}$ & Gargle & Oral Lichen Planus & $120 \mathrm{~J} / \mathrm{cm}^{2}$ & $632 \mathrm{~nm}$ & $\begin{array}{l}\text { Aghahosseini } \mathrm{F}, \\
\text { et al. }[108]\end{array}$ \\
\hline 2009 & 16 & $0,1 \%$ hydrogel & Topically & $\begin{array}{l}\text { Resistant psoriatic } \\
\text { plaque }\end{array}$ & $565 \mathrm{~mW}$ & $670 \mathrm{~nm}$ & Salah M, et al. [109] \\
\hline 2014 & 80 & $\begin{array}{l}2 \% \text { aqueous } \\
\text { solution }\end{array}$ & Oral administration & onychomycosis & $18 \mathrm{~J} / \mathrm{cm}^{2}$ & $630 \mathrm{~nm}$ & $\begin{array}{c}\text { Figueiredo Souza L W, } \\
\text { et al. }[110]\end{array}$ \\
\hline 2009 & 13 & $0,1 \%$ hydrogel & Topically & Acne vulgaris & & & Fadel M, et al. [111] \\
\hline 2014 & 18 & $\begin{array}{l}1 \% \text { aqueous } \\
\text { solution }\end{array}$ & $\begin{array}{l}\text { Irrigation using } \\
\text { syringes and } \\
\text { catheters }\end{array}$ & $\begin{array}{l}\text { Neuropathy, ulceration } \\
\text { and infection in diabetic } \\
\text { patin }\end{array}$ & $30 \mathrm{~J} / \mathrm{cm}^{2}$ & 400 to $725 \mathrm{~nm}$ & Tardivo JP, et al. [112] \\
\hline 1995 & 3 & $\begin{array}{l}1 \% \text { aqueous } \\
\text { solution }\end{array}$ & Intratumor injection & $\begin{array}{c}\text { Inoperable oesophageal } \\
\text { tumours }\end{array}$ & $7 \mathrm{~J} / \mathrm{cm}^{2}$ & $662 \mathrm{~nm}$ & Orth K, et al. [52] \\
\hline 2012 & 12 & $0.01 \%$ & $\begin{array}{l}\text { applied at the } \\
\text { bottom of the } \\
\text { periodontal pocket }\end{array}$ & $\begin{array}{l}\text { Periodontitis in HIV } \\
\text { patients }\end{array}$ & $0,03 \mathrm{~W}$ & $660 \mathrm{~nm}$ & Noro Filho, et al. [113] \\
\hline
\end{tabular}

Photosensitizers can be classified according to their structure or origin. A traditional classification separates these compounds into three generations. Porphyrins and other substances developed in the 70's or early 80 's are named first-generation photosensitizers, while porphyrin derivatives or synthetic compounds produced in the late 80 's are termed second-generation photosensitizers. Third generation photosensitizers refer to changes carried out in their structures leading to selective tumor accumulation, like organic conjugates (liposomes or conjugated to antibodies) $[32,35]$. Furthermore, existing photosensitizers can be classified into three large families: (1) porphyrinbased photosensitizers (eg, Photofrin, ALA/PpIX, BPDMA); (2) chlorophyll-based photosensitizers (eg chlorins, purplish, bacteriochlorins); and (3) dyes (phthalocyanines, naphthalocyanines, methylene blue) [35].

Clinically- or experimentally-applied photosensitizers include many metallocomplexes which generally exhibit maximum absorption bands in the visible red spectrum and a molar extinction coefficient ranging from $10^{3}$ to $10^{5} \mathrm{M}^{-1}$. $\mathrm{cm}^{-1}$ [37]. Most are based on a tetrapyrrole aromatic nucleus, similar to the protoporphyrin found in hemoglobin. These rings exhibit a relatively broad absorption band in the 400 $\mathrm{nm}$ region, known as the Soret band, and a group of minor bands directed to red wavelengths, known as the Q-band [38]. Hematoporphyrin derivatives $(\mathrm{HpD})$ and porfirmer sodium
(Photofrin) obtained from subsequent purifications are prototype drugs and were the first to be applied in the clinical practice. Despite their success as tools for the treatment of cancer and other conditions, these compounds display some disadvantages, such as lack of chemical homogeneity, slow skin clearance, resulting in long-term photosensitivity, and poor absorption in the clinical wavelength $\left(\varepsilon=10^{3} \mathrm{M}^{-1} \cdot \mathrm{cm}^{-1}\right.$ at $640 \mathrm{~nm}$ ), where light shows adequate tissue penetration [14, 36]. This has motivated the search for new photosensitizers that would exceed these limitations and present appropriate photophysical and photochemical properties.

\section{Methylene blue (MB) characteristics}

Among second-generation photosensitizers, phenothiazine dyes are noted for displaying desirable photophysical and photochemical characteristics for PDT applications, such as high production of singlet oxygen species and strong absorption in therapeutic range (600$750 \mathrm{~nm}$ ) [39]. Chemically, these compounds are formed by two main portions, namely chromospheres, which are aromatic ring systems with delocalized p-electrons, and peripheral modifications, such as side chains and auxochromes. This heterocyclic ring system has long been established and its chemical synthesis is well understood, allowing for easy analogue preparation [40]. Two main 
classes of phenothiazines are used in the medical practice: oxidized phenothiazines, planar and tricyclic (MB, thionine and toluidine blue), and non-oxidized molecules, such as promethazine and chlorpromazine, that are not completely aromatic or planar. Typically, phenothiazine dyes present a delocalized positive charge at neutral $\mathrm{pH}$ in the ring system, whereas phenothiazine neuroleptics exhibit a positive charge located at the nitrogen distal side chain. Phenothiazine compounds display great versatility concerning possible applications in medical practice, and are studied regarding their therapeutic role in the local treatment of bacterial infections, tuberculosis, trypanosomiasis, malaria, rickettsia infections, fungal infections and cancer [41]. Regarding cancer PDT applications, the most researched compounds are methylene blue (IUPAC name: 3,7-bis(Dimethylamino)phenothiazin-5-ium chloride) and toluidine blue, which are structurally and physicochemically similar. Both possess a nitrogen atom capable of accepting protons in the center ring and two nitrogen atoms that contribute to charge relocation in the chromophore by stabilizing the cationic form.

MB has been widely applied as a vital dye for over a century $[42,43]$. It was first synthesized in the nineteenth century (1876) by Heinrich Caro, who worked at Badische Anilin und Soda-Fabrik, a German chemical industry, from the oxidation of p-dimethylaniline [44]. In the late nineteenth century, scientists Robert Koch and Paul Ehrlich used MB to stain microorganisms. Based on these studies, Erlich envisioned that these could also be applied therapeutically. In fact, in 1891, he demonstrated that MB was effective in treating malaria in humans [45].

MB shows an intense color in aqueous solutions due to the intense absorption of the phenothiazine chromophore at

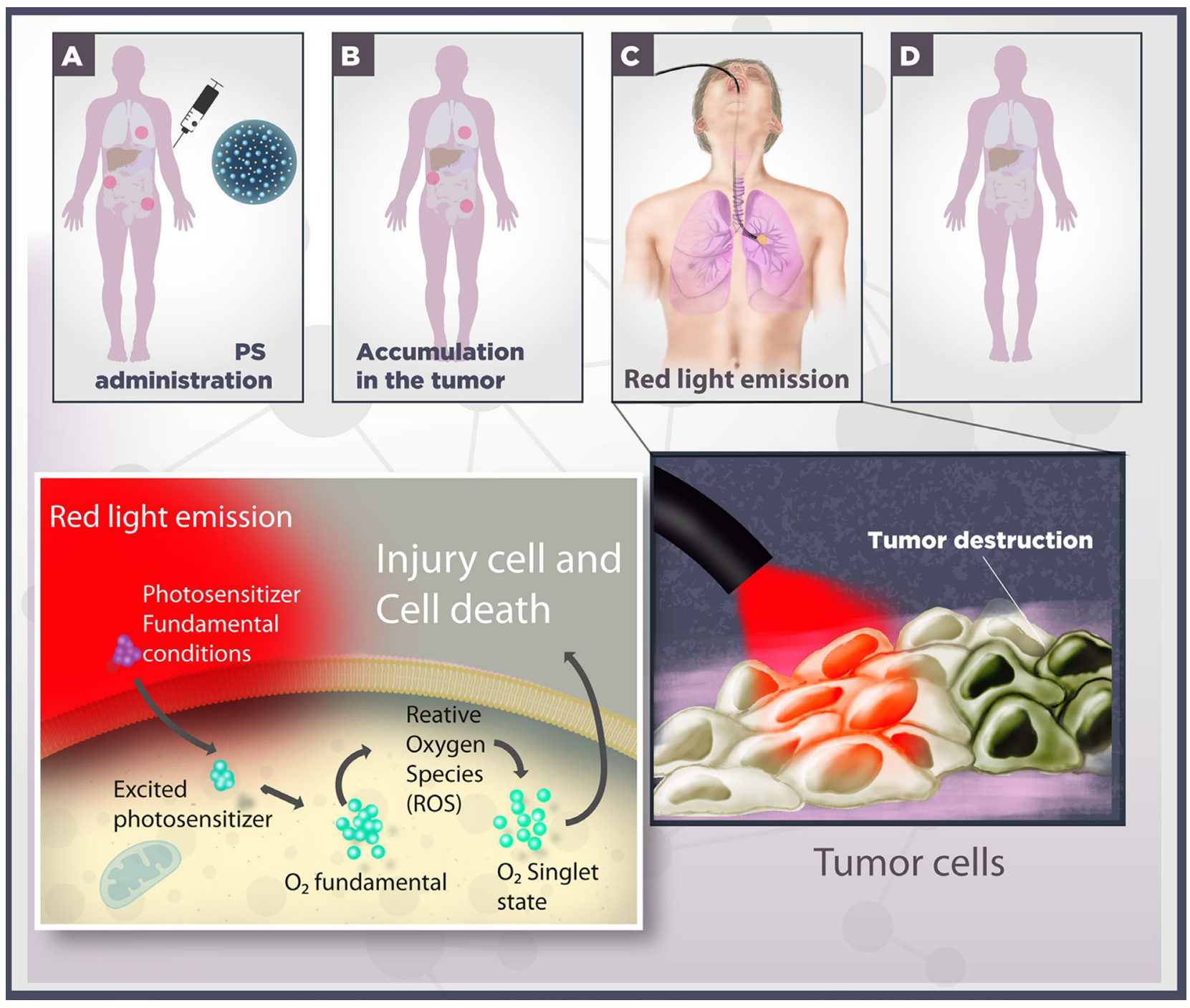

Figure 1: Schematic representation of photodynamic therapy. (A) A photosensitizer (PS) is systemically or topically administered. (B) After systemic PS distribution, it selectively accumulates in the tumor, represented by red circles. (C) In cooperation to laparoscopic techniques, the cancer cells are irradiated with red light. Irradiation activates the PS and triggers a photochemical reaction in the presence of molecular oxygen, culminating in the production of singlet oxygen species (1O2). (D) Damage to cellular macromolecules leads to tumor cell death by different processes, such as apoptotic, necrotic and autophagic mechanisms. 
$600-700 \mathrm{~nm}$ in the visible spectrum, with a well-defined peak at 664-666 nm [39, 46]. A less intense peak can be observed in or near the UV region, particularly from 284 to $300 \mathrm{~nm}$ [42]. Moreover, this compound can also generate radicals, even in the presence of reducing agents [46]. In aqueous solutions, the excitation spectrum is concentration-dependent due to dimerization and oligomerization phenomena, whose equilibrium constant is $3.8 \times 10^{-3} \mathrm{M}^{-1}$ [46]. Between $10^{-5}$ and $10^{-3} \mathrm{M}, \mathrm{MB}$ aggregation is limited to dimer formation. Dimerization increases with ionic strength and can increase or decrease the presence of charged interfaces, depending on the relationship between the dye and the interface [47]. Monomers and dimers have very distinct absorption bands, with the dimer band $60 \mathrm{~nm}$ shorter compared to the monomer band. Similarly to many inorganic dyes, MB does not follow the Beer-Lambert law [43], probably due to the reversible formation of polymers, which are maintained together by the dispersion forces originating from delocalized $\mathrm{p}$ electrons in the individual dye molecules [44]. The photodynamic mechanism for $\mathrm{MB}$ is quite complex. It has a high quantum yield of intersystem crossing $\left(\Phi_{\Delta} \sim 0.5\right)$, which can generate high singlet oxygen species concentrations and mediate cytotoxicity to form hydroxyl radicals, which in turn can alter intracellular $\mathrm{Ca}^{2+}$ homeostasis [48, 49].

$\mathrm{MB}$ is characterized by its low toxicity and can be used in the intraoperative or endoscopic marking of various tumors, as well as in the clinical treatment for methemoglobinemia [14, 49]. Although idiosyncratic reactions may occur, $\mathrm{MB}$ doses are high without the occurrence of measurable toxicity. For example, concentrations routinely used for staining the oral and nasopharyngeal mucosa are in the millimole range $(1 \% \mathrm{w} / \mathrm{w}$ or $31,2 \mathrm{mM})$ [39]. Additionally, MB pharmacokinetics are well established and have shown different distribution profiles, depending on the administration route [50].

Several studies considering MB for the treatment of neoplasms have been reported. In vitro studies have demonstrated that MB shows phototoxicity against several tumor cell lines, such as cervical cancer adenocarcinomas (HeLa) and bladder carcinomas [51]. Local MB administration has also been applied in the treatment of inoperable esophageal tumor [52]. However, oncology MB clinical applications have been limited due to its lack of activity when applied systemically. This weak pharmaceutical activity results in poor penetration of tumor cellular environment [53].

\section{Strategies to improve MB cell entry}

In this scenario, it is, thus, essential to search for pathways that may facilitate MB a hydrophilic drug, uptake into target cells, leading to feasible tumor treatments. In this context, pore-forming proteins are present in the plasma membrane of many mammalian cell types, able to open under physiological or pathophysiological conditions, such as changes in cell volume, hypoxia and alterations in extracellular $\mathrm{pH}$, among others. When open, they allow for the passage of molecules of up to 1,000 Da without necessarily leading to cell death. Among pore-forming proteins, pannexin-1 [54], connexin hemichannels [55], TRPV1-4 subtypes and TRPA1 [56], calcium homeostasis modulator 1 (CALHM1) [57], Maxi anion [58], plasma membrane VDAC [59] and ATP-gated subtypes P2X2 [60-62], P2X4 [63-65] and, especially, $\mathrm{P} 2 \mathrm{X} 7$ receptors [66-68] are noteworthy (Figure 2). One possibility would be to study the involvement of the P2X7 associated-pore as an MB uptake route in the cytoplasm of neoplastic cells, and, in this regard, we have recently demonstrated that P2X7 can function as a drug delivery system in the J774 tumor cell line [69].

Since this receptor is related to several physiological processes, such as T-cell maturation, innate immune response activation, epithelial secretion, mineralization regulation, bone resorption and fast synaptic transmission, among others, it is not surprising that it is also associated to several pathological conditions. Indeed, P2X7 polymorphisms have been associated with susceptibility to infectious neurodegenerative diseases, depression, osteoporosis and inflammatory diseases [70-77].

In this context, several groups have investigated the role of $\mathrm{P} 2 \mathrm{X} 7$ in tumor pathophysiology, mainly due to its cytotoxic potential, which can exploited as a pharmacological target. Its expression (mRNA and protein) has been demonstrated in different tumor and tumor cell lines subtype (Table 3), but no consensus ion its function has been reached. Nevertheless, evidence clearly shows a dependence on the cellular model under study, as this receptor may be involved with growth/proliferation or death induction (apoptosis/necrosis) [78-84].

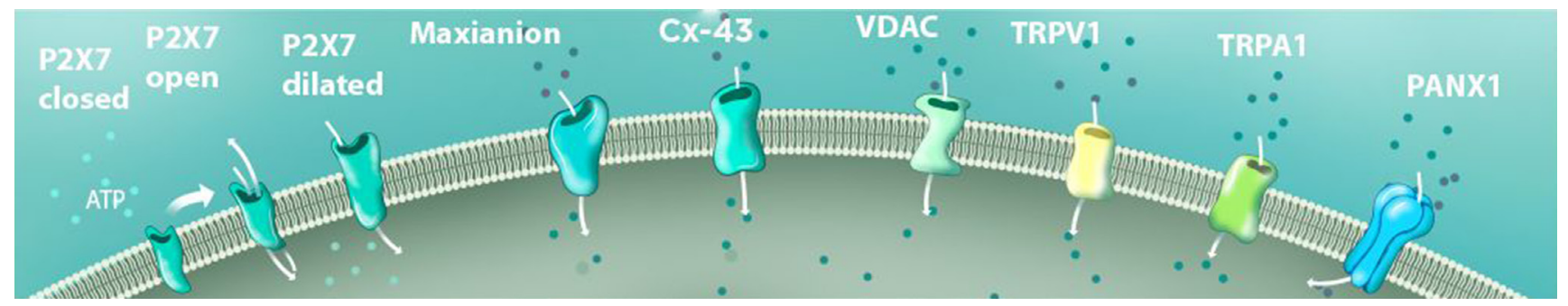

Figure 2: Using the pore associated with P2X7 receptor and other pores as an entry pathway for methylene blue (319 Da) in PDT. 


\section{$\mathrm{MB}$ and the $\mathrm{P} 2 \mathrm{X} 7$ receptor}

Although knowledge on tumor biology has advanced greatly in recent years, the approval of new cancer treatment drugs is still limited. In addition, traditional therapies, such as chemotherapy and radiotherapy, lack selectivity and possess numerous side effects. Accordingly, PDT emerges as a promising alternative, displaying very positive results over the years. MB stands out among photosensitizers with possible applications in clinical practice, since it displays excellent photodynamic properties and low toxicity in humans. However, its use has been limited due to its low tumor penetration $[85,86]$ The literature describes several strategies to increase MB uptake by tumor tissues, such as altering its chemical structure in order to increase lipophilicity, or its association with three-dimensional structures, allowing access to the cytoplasm, as cited previously. Herein, we propose another possibility, of using transient membrane pores, such as the pore induced by activation of the $\mathrm{P} 2 \mathrm{X} 7$ receptor. Interestingly, this receptor has been described in certain types of tumors, making it an adequate target for pharmacological tumor therapy. This strategy could enhance PDT once MB is at a size able to pass through the pore ( $319 \mathrm{Da})$. Figure 3 displays a scheme representing this hypothesis, in which a cell is exposed to MB along with ATP administration at concentrations sufficient enough to open the $\mathrm{P} 2 \mathrm{X} 7$ pore for 15 to 20 minutes. After the incubation period, the cells would be exposed to light in the appropriate wavelength (600-700 $\mathrm{nm}$ ) in order to activate MB photodynamic activity.

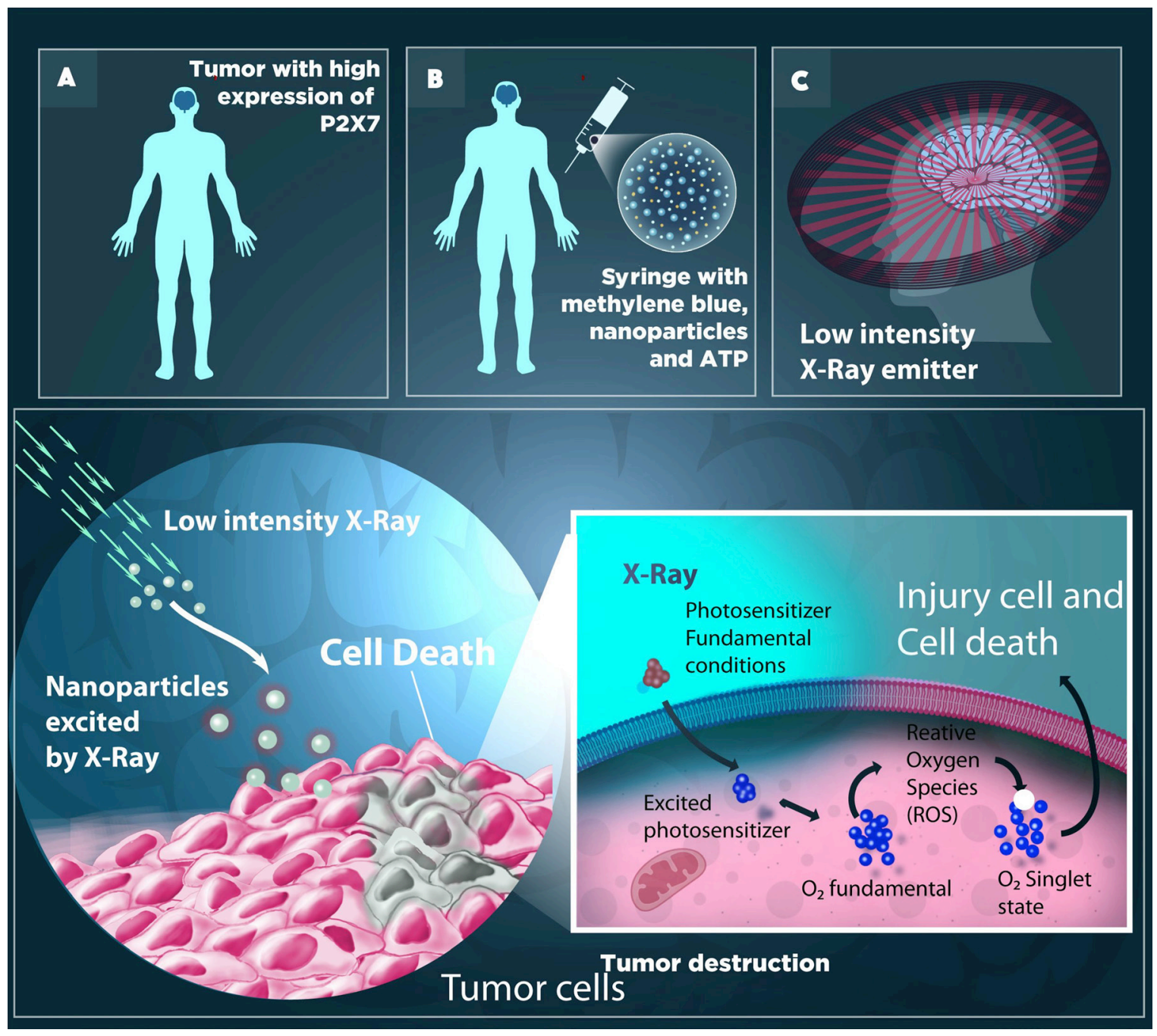

Figure 3: Photodynamic therapy may increase selectivity when applied concurrently to photosensitizing (PS) radioluminescent molecules (RL). (A) A tumor with high P2X7 expression can be treated with the application of Methylene blue (MB), a potent Photosensitizer (PS), nanoparticles and ATP. (B) These compounds in solution form are administered directly into the venous circulation via syringe and, once in the blood, can migrate to any part of the body. ATP administration activates the pore associated to the P2X7 receptor, allowing for MB passage. (C) The RL, once excited by low intensity X-rays, emit luminescence in the red spectrum. Thus, the luminescence produced by the radioluminescent molecule leads to an excited state of the photosensitizer (PS*), initiating a series of photochemical reactions in the tumor environment, resulting in the production of singlet oxygen species (1O2) from molecular oxygen (3O2), which is a highly reactive and cytotoxic chemical species. 
Table 3: P2X7 expression and functions in neoplasms

\begin{tabular}{|c|c|c|c|c|}
\hline Year & Tumor type & Expression level & $\begin{array}{c}\text { Physiological effect of the } \\
\text { activation }\end{array}$ & References \\
\hline 2005 & Prostate & Protein & No determined & Slater M, et al. [114] \\
\hline 2013 & Breast & mRNA/Protein & $\begin{array}{l}\text { Increases intracellular } \mathrm{Ca}^{2+} \\
\text { concentration }\end{array}$ & Jelassi B, et al. [115] \\
\hline 2008 & Thyroid & mRNA/Protein & Not determined & Solini A, et al. [116] \\
\hline 2007 & Pancreas & mRNA & Not determined & Kunzli BM, et al. [117] \\
\hline 2005 & Skin carcinoma & mRNA & Not determined & Slater M, et al. [114] \\
\hline 2006 & Uterine epithelial & mRNA/Protein & Not determined & Li X, et al. [118] \\
\hline 2006 & Neuroblastoma & mRNA/Protein & Induce cell proliferation & Raffaghello L, et al. [119] \\
\hline 2005 & Melanoma & mRNA/Protein & YO-PRO-1 uptake & White $\mathrm{N}$, et al. [120] \\
\hline 2002 & $\begin{array}{l}\text { Chronic Lymphocytic } \\
\text { Leukemia }\end{array}$ & mRNA/Protein & Decrease the proliferation & Adinolfi E, et al. [121] \\
\hline 2015 & $\begin{array}{l}\text { Hepatocellular } \\
\text { carcinoma }\end{array}$ & mRNA/Protein & Not determined & Liu H, et al. [122] \\
\hline 2014 & Ovarian carcinoma & mRNA/Protein & $\begin{array}{c}\text { Increase of intracellular } \mathrm{Ca}^{2+} \\
\text { concentration, but not cell } \\
\text { death }\end{array}$ & $\begin{array}{l}\text { Vázquez-Cuevas FG, } \\
\text { et al. }[123]\end{array}$ \\
\hline 2010 & $\begin{array}{l}\text { Papillary thyroid } \\
\text { carcinoma }\end{array}$ & Protein & Not determined & Gu LQ, et al. [124] \\
\hline 2012 & Lung cancer & mRNA/Protein & Ethidium uptake & Takai E, et al. [125] \\
\hline 2012 & Glioma & mRNA/Protein & Ethidium uptake & Gehring MP, et al. [126] \\
\hline 2013 & Colorectal cancer & mRNA & Ethidium uptake & Bian S, et al. [127] \\
\hline
\end{tabular}

Furthermore, following the system upgrades as displayed in Figure 3, radioluminescent molecules, which produce luminescence in the red spectrum excited by low-intensity $\mathrm{X}$-ray, would become even more selective and exhibit fewer side effects [87], as previously outlined in Figure 3.

\section{CONFLICTS OF INTEREST}

None.

\section{REFERENCES}

1. Von Tappeiner H, Jodlbauer A. Über die Wirkung der photodynamischen (fluorescierenden) Stoffe auf Protozoen und Enzyme. Dtsch Arch Klin Med. 1904; 80:427-87.

2. Von Tappeiner H, Jodlbauer A. Die Sensibilisierende Wirkung fluorieszierender Substanzer Gesammte Untersuchungen uber die photodynamische Erscheinung. FCW Vogel Leipzig. 1907.

3. Von Tappeiner H. Ueber die Wirkung fluorescierender Stoffe auf Infusorien nach Versuchen von O. Raab. Munch Med Wochenschr. 1900; 1:5-7.
4. Raab O. Ueber die Wirkung fluorescierender Stoffe auf Infusorien. Z Biol. 1900; 39:524-46.

5. Marcacci A. Sur l'action des alcaloides dans les regne vegetal et animal. Arch Ital Biol. 1888; 9:2-4.

6. Prime J. Les accidentes toxiques par I'eosinate de sodium. Jouve \& Boyer. 1900.

7. Von Tappeiner H, Jesionek A. Therapeutische Versuche mit fluoreszierenden Stoffen. Munch Med Wochenschr. 1903; 47:2042-44.

8. Jesionek A, Von Tappeiner H. Zur Behandlung der Hautcarcinome mit fluorescierenden Stoffen. Dtsch Arch Klin Med. 1905; 82:223-27.

9. Diamond I, Granelli SG, McDonagh AF, Nielsen S, Wilson CB, Jaenicke R. Photodynamic therapy of malignant tumours. Lancet. 1972; 2:1175-77. https://doi.org/10.1016/ S0140-6736(72)92596-2.

10. Dougherty TJ, Grindey GB, Fiel R, Weishaupt KR, Boyle DG. Photoradiation therapy. II. Cure of animal tumors with hematoporphyrin and light. J Natl Cancer Inst. 1975; 55:115-21. https://doi.org/10.1093/ jnci/55.1.115. 
11. Kick G, Messer G, Plewig G. Historische Entwicklung der Photodynamischen Therapie. Hautarzt. Springer-Verlag. 1996; 644-9. https://doi.org/10.1007/s001050050485.

12. Juz P. History and basic principles of photodynamic therapy. PDT. 2005.

13. Wainwright M, Phoenix DA, Rice L, Burrow SM, Waring $\mathrm{J}$. Increased cytotoxicity and phototoxicity in the methylene blue series via chromophore methylation. J Photochem Photobiol B. 1997; 40:233-39. https://doi.org/10.1016/ S1011-1344(97)00061-4.

14. Sharman WM, Allen CM, van Lier JE. Photodynamic therapeutics: basic principles and clinical applications. Drug Discov Today. 1999; 4:507-17. https://doi.org/10.1016/ S1359-6446(99)01412-9.

15. Allison RR, Sibata CH. Oncologic photodynamic therapy photosensitizers: a clinical review. Photodiagn Photodyn Ther. 2010; 7:61-75. https://doi.org/10.1016/j. pdpdt.2010.02.001

16. Ochsner M. Photophysical and photobiological processes in the photodynamic therapy of tumours. J Photochem Photobiol B. 1997; 39:1-18. https://doi.org/10.1016/S10111344(96)07428-3.

17. Triesscheijn M, Baas $\mathrm{P}$, Schellens JH, Stewart FA. Photodynamic therapy in oncology. Oncologist. 2006; 11:1034-44. https://doi.org/10.1634/theoncologist.11-9-1034.

18. Simplicio FI, Maionchi F, Hioka N. Terapia fotodinâmica: aspectos farmacológicos, aplicações e avanços recentes no desenvolvimento de medicamentos. Quim Nova. 2002; 25:80107. https://doi.org/10.1590/S0100-40422002000500016.

19. Brown SB, Brown EA, Walker I. The present and future role of photodynamic therapy in cancer treatment. Lancet Oncol. 2004; 5:497-508. https://doi.org/10.1016/S14702045(04)01529-3.

20. Dougherty TJ, Gomer CJ, Henderson BW, Jori G, Kessel D, Korbelik M, Moan J, Peng Q. Photodynamic therapy. J Natl Cancer Inst. 1998; 90:889-905. https://doi.org/10.1093/ jnci/90.12.889.

21. Luksiene Z. Photodynamic therapy: mechanism of action and ways to improve the efficiency of treatment. Medicina (Kaunas). 2003; 39:1137-50.

22. Chen W, Zhang J. Using nanoparticles to enable simultaneous radiation and photodynamic therapies for cancer treatment. J Nanosci Nanotechnol. 2006; 6:1159-66. https://doi.org/10.1166/jnn.2006.327.

23. Bawa R. Nanoparticle-based therapeutics in humans: A survey. Nanotechnol Law Bus. 2008; 5:135-55.

24. Maisch T. A new strategy to destroy antibiotic resistant microorganisms: antimicrobial photodynamic treatment. Mini Rev Med Chem. 2009; 9:974-83. https://doi.org/10. 2174/138955709788681582.

25. Mang TS, Tayal DP, Baier R. Photodynamic therapy as an alternative treatment for disinfection of bacteria in oral biofilms. Lasers Surg Med. 2012; 44:588-96. https://doi. org/10.1002/1sm.22050.
26. Hamblin MR, Hasan T. Photodynamic therapy: a new antimicrobial approach to infectious disease? Photochem Photobiol Sci. 2004; 3:436-50. https://doi.org/10.1039/b311900a.

27. Yano S, Hirohara S, Obata M, Hagiya Y, Ogura SI, Ikeda A, Kataoka H, Tanaka M, Joh T. Current states and future views in photodynamic therapy. J Photochem Photobiol C Photochem Rev. Elsevier B.V. 2011; 12:46-67. https://doi. org/10.1016/j.jphotochemrev.2011.06.001.

28. Agostinis P, Berg K, Cengel KA, Foster TH, Girotti AW, Gollnick SO, Hahn SM, Hamblin MR, Juzeniene A, Kessel D, Korbelik M, Moan J, Mroz P, et al. Photodynamic therapy of cancer: an update. CA Cancer J Clin. 2011; 61:250-81. https://doi.org/10.3322/caac.20114.

29. Palumbo G. Photodynamic therapy and cancer: a brief sightseeing tour. Expert Opin Drug Deliv. 2007; 4:131-48. https://doi.org/10.1517/17425247.4.2.131.

30. Juarranz A, Jaén P, Sanz-Rodríguez F, Cuevas J, González S. Photodynamic therapy of cancer. Basic principles and applications. Clin Transl Oncol. 2008; 10:148-54. https:// doi.org/10.1007/s12094-008-0172-2.

31. Yoon I, Li JZ, Shim YK. Advance in photosensitizers and light delivery for photodynamic therapy. Clin Endosc. 2013; 46:7-23. https://doi.org/10.5946/ce.2013.46.1.7.

32. Allison RR, Downie GH, Cuenca R, Hu XH, Childs CJ, Sibata $\mathrm{CH}$. Photosensitizers in clinical PDT. Photodiagn Photodyn Ther. 2004; 1:27-42. https://doi.org/10.1016/ S1572-1000(04)00007-9.

33. DeRosa MC, Crutchley RJ. Photosensitized singlet oxygen and its applications. Coord Chem Rev. 2002; 233-234:35171. https://doi.org/10.1016/S0010-8545(02)00034-6.

34. Phillips D. Light relief: photochemistry and medicine. Photochem Photobiol Sci. Royal Society of Chemistry. 2010; 9:1589. https://doi.org/10.1039/c0pp00237b.

35. Huang Z. A review of progress in clinical photodynamic therapy. Technol Cancer Res Treat. 2005; 4:283-93. https:// doi.org/10.1177/153303460500400308.

36. Reddy VN, Rekha Rani K, Chandana G, Sehrawat S, Krishnkumar R. Photodynamic Therapy. INDIAN J Dent Adv. 2009; 1.

37. Ali H, van Lier JE. Metal complexes as photo- and radiosensitizers. Chem Rev. 1999; 99:2379-450. https:// doi.org/10.1021/cr980439y.

38. Castano AP, Demidova TN, Hamblin MR. Mechanisms in photodynamic therapy: part one-photosensitizers, photochemistry and cellular localization. Photodiagn Photodyn Ther. 2004; 1:279-93. https://doi.org/10.1016/ S1572-1000(05)00007-4.

39. Wainwright M. Methylene blue derivatives - suitable photoantimicrobials for blood product disinfection? Int J Antimicrob Agents. 2000; 16:381-94. https://doi. org/10.1016/S0924-8579(00)00207-7.

40. Perussi JR. Inativação fotodinâmica de microrganismos. Quim Nova. 2007; 30:988-94. https://doi.org/10.1590/ S0100-40422007000400039. 
41. Wainwright M, Giddens RM. Phenothiazinium photosensitisers: choices in synthesis and application. Dyes Pigments. 2003; 57:245-57. https://doi.org/10.1016/S01437208(03)00021-4.

42. Floyd RA, Schneider JE Jr, Dittmer DP. Methylene blue photoinactivation of RNA viruses. Antiviral Res. 2004; 61:141-51. https://doi.org/10.1016/j.antiviral.2003.11.004.

43. Sheppard SE, Geddes AL. Effect of Solvents upon the Absorption Spectra of Dyes. IV. Water as Solvent: A Common Pattern. J Am Chem Soc. 1944; 66:1995-2002. https://doi.org/10.1021/ja01240a001.

44. Sheppard S. The Effects of Environment and Aggregation on the Absorption Spectra of Dyes. Rev Mod Phys. 1942; 14:303-40. https://doi.org/10.1103/RevModPhys.14.303.

45. Wainwright M, Crossley KB. Methylene Blue-a therapeutic dye for all seasons? J Chemother. 2002; 14:43143. https://doi.org/10.1179/joc.2002.14.5.431.

46. Tardivo JP, Del Giglio A, De Oliveira CS, Gabrielli DS, Junqueira HC, Tada DB, Severino D, De F. tima Turchiello $\mathrm{R}$, Baptista MS. Methylene blue in photodynamic therapy: from basic mechanisms to clinical applications. Photodiagn Photodyn Ther. 2005; 2:175-91. https://doi.org/10.1016/ S1572-1000(05)00097-9.

47. Severino D, Junqueira HC, Gugliotti M, Gabrielli DS, Baptista MS. Influence of negatively charged interfaces on the ground and excited state properties of methylene blue. Photochem Photobiol. 2003; 77:459-68. https://doi. org/10.1562/0031-8655(2003)077<0459:IONCIO >2.0. $\mathrm{CO} ; 2$.

48. Tuite EM, Kelly JM. New trends in photobiology. J Photochem Photobiol B. 1993; 21:103-24. https://doi. org/10.1016/1011-1344(93)80173-7.

49. Orth K, Beck G, Genze F, Rück A. Methylene blue mediated photodynamic therapy in experimental colorectal tumors in mice. J Photochem Photobiol B. 2000; 57:186-92. https:// doi.org/10.1016/S1011-1344(00)00105-6.

50. Peter C, Hongwan D, Küpfer A, Lauterburg BH. Pharmacokinetics and organ distribution of intravenous and oral methylene blue. Eur J Clin Pharmacol. 2000; 56:24750. https://doi.org/10.1007/s002280000124.

51. Lu Y, Jiao R, Chen X, Zhong J, Ji J, Shen P. Methylene blue-mediated photodynamic therapy induces mitochondriadependent apoptosis in HeLa cell. J Cell Biochem. 2008; 105:1451-60. https://doi.org/10.1002/jcb.21965.

52. Orth K, Rück A, Stanescu A, Beger HG. Intraluminal treatment of inoperable oesophageal tumours by intralesional photodynamic therapy with methylene blue. Lancet. 1995; 345:519-20. https://doi.org/10.1016/S01406736(95)90617-7.

53. Tang W, Xu H, Kopelman R, Philbert MA. Photodynamic characterization and in vitro application of methylene bluecontaining nanoparticle platforms. Photochem Photobiol. 2005; 81:242-49. https://doi.org/10.1562/2004-05-24RA-176.1.
54. Pelegrín P, Surprenant A. Pannexin-1 mediates large pore formation and interleukin-1beta release by the ATP-gated P2X7 receptor. EMBO J. 2006; 25:5071-82. https://doi. org/10.1038/sj.emboj.7601378.

55. Stout CE, Costantin JL, Naus CC, Charles AC. Intercellular calcium signaling in astrocytes via ATP release through connexin hemichannels. J Biol Chem. 2002; 277:10482-88. https://doi.org/10.1074/jbc.M109902200.

56. Ferreira LG, Faria RX. TRPing on the pore phenomenon: what do we know about transient receptor potential ion channelrelated pore dilation up to now? J Bioenerg Biomembr. 2016; 48:1-12. https://doi.org/10.1007/s10863-015-9634-8.

57. Ma Z, Siebert AP, Cheung KH, Lee RJ, Johnson B, Cohen AS, Vingtdeux V, Marambaud P, Foskett JK. Calcium homeostasis modulator 1 (CALHM1) is the pore-forming subunit of an ion channel that mediates extracellular $\mathrm{Ca} 2+$ regulation of neuronal excitability. Proc Natl Acad Sci USA. 2012; 109:E1963-71. https://doi.org/10.1073/ pnas. 1204023109.

58. Islam MR, Uramoto H, Okada T, Sabirov RZ, Okada Y. Maxi-anion channel and pannexin 1 hemichannel constitute separate pathways for swelling-induced ATP release in murine L929 fibrosarcoma cells. Am J Physiol Cell Physiol. 2012; 303:C924-35. https://doi.org/10.1152/ ajpcell.00459.2011.

59. Sabirov RZ, Merzlyak PG. Plasmalemmal VDAC controversies and maxi-anion channel puzzle. Biochim Biophys Acta. 2012; 1818:1570-80. https://doi. org/10.1016/j.bbamem.2011.09.024.

60. Khakh BS, Egan TM. Contribution of Transmembrane Regions to ATP-gated P2X 2 Channel Permeability Dynamics*. 2004. https://doi.org/10.1074/jbc.M411324200.

61. Chaumont S, Khakh BS. Patch-clamp coordinated spectroscopy shows $\mathrm{P} 2 \mathrm{X} 2$ receptor permeability dynamics require cytosolic domain rearrangements but not Panx-1 channels. Proc Natl Acad Sci U S A. National Academy of Sciences. 2008; 105:12063-8. https://doi.org/10.1073/ pnas.0803008105.

62. Marques-da-Silva C, Chaves MM, Castro NG, CoutinhoSilva R, Guimaraes MZ. Colchicine inhibits cationic dye uptake induced by ATP in P2X2 and P2X7 receptorexpressing cells: implications for its therapeutic action. $\mathrm{Br}$ J Pharmacol. Wiley-Blackwell. 2011; 163:912-26. https:// doi.org/10.1111/j.1476-5381.2011.01254.x.

63. Bernier LP, Ase AR, Boué-Grabot É, Séguéla P. P2X4 receptor channels form large noncytolytic pores in resting and activated microglia. Glia. Wiley Subscription Services, Inc., A Wiley Company. 2012; 60:728-37. https://doi. org/10.1002/glia.22301.

64. Miklavc P, Mair N, Wittekindt OH, Haller T, Dietl P, Felder E, Timmler M, Frick M. Fusion-activated $\mathrm{Ca} 2+$ entry via vesicular P2X 4 receptors promotes fusion pore opening and exocytotic content release in pneumocytes. Proc Natl Acad Sci USA. 2011; 108:14503-08. https://doi.org/10.1073/ pnas. 1101039108 . 
65. Carneiro MV, Americo TA, Guimarães MZ, Linden R. The prion protein selectively binds to and modulates the content of purinergic receptor P2X4R. Biochem Biophys Res Commun. 2016; 472:293-98. https://doi.org/10.1016/j. bbrc.2016.02.122.

66. Yan Z, Li S, Liang Z, Tomić M, Stojilkovic SS. The P2X7 receptor channel pore dilates under physiological ion conditions. J Gen Physiol. 2008; 132:563-73. https://doi. org/10.1085/jgp.200810059.

67. Faria RX, Cascabulho CM, Reis RA, Alves LA. Largeconductance channel formation mediated by $\mathrm{P} 2 \mathrm{X} 7$ receptor activation is regulated through distinct intracellular signaling pathways in peritoneal macrophages and 2BH4 cells. Naunyn Schmiedebergs Arch Pharmacol. 2010; 382:73-87. https://doi.org/10.1007/s00210-010-0523-8.

68. Faria RX, Reis RA, Ferreira LG, Cezar-de-Mello PF, Moraes MO. P2X7R large pore is partially blocked by pore forming proteins antagonists in astrocytes. J Bioenerg Biomembr. 2016; 48:309-24. https://doi.org/10.1007/ s10863-016-9649-9.

69. Pacheco PA, Ferreira LB, Mendonça L, Ferreira DN, Salles JP, Faria RX, Teixeira PC, Alves LA. P2X7 receptor as a novel drug delivery system to increase the entrance of hydrophilic drugs into cells during photodynamic therapy. J Bioenerg Biomembr. J Bioenerg Biomembr. 2016. https:// doi.org/10.1007/s10863-016-9668-6.

70. Takenouchi T, Sekiyama K, Sekigawa A, Fujita M, Waragai M, Sugama S, Iwamaru Y, Kitani H, Hashimoto M. P2X7 receptor signaling pathway as a therapeutic target for neurodegenerative diseases. Arch Immunol Ther Exp (Warsz). 2010; 58:91-96. https://doi.org/10.1007/s00005010-0069-y.

71. Skaper SD, Debetto P, Giusti P. The P2X7 purinergic receptor: from physiology to neurological disorders. FASEB J. 2010; 24:337-45. https://doi.org/10.1096/fj.09-138883.

72. Lister MF, Sharkey J, Sawatzky DA, Hodgkiss JP, Davidson DJ, Rossi AG, Finlayson K. The role of the purinergic P2X7 receptor in inflammation. J Inflamm (Lond). 2007; 4:5. https://doi.org/10.1186/1476-9255-4-5.

73. Kurashima Y, Amiya T, Nochi T, Fujisawa K, Haraguchi T, Iba H, Tsutsui H, Sato S, Nakajima S, Iijima H, Kubo M, Kunisawa J, Kiyono H. Extracellular ATP mediates mast cell-dependent intestinal inflammation through P2X7 purinoceptors. Nat Commun. 2012; 3:1034. https://doi. org/10.1038/ncomms2023.

74. Wesselius A, Bours MJ, Henriksen Z, Syberg S, Petersen S, Schwarz P, Jørgensen NR, van Helden S, Dagnelie PC. Association of $\mathrm{P} 2 \mathrm{X} 7$ receptor polymorphisms with bone mineral density and osteoporosis risk in a cohort of Dutch fracture patients. Osteoporos Int. 2013; 24:1235-46. https:// doi.org/10.1007/s00198-012-2059-x.

75. Bennett MR. Synaptic P2X7 receptor regenerative-loop hypothesis for depression. Aust N Z J Psychiatry. 2007; 41:563-71. https://doi.org/10.1080/00048670701399994.
76. Basso AM, Bratcher NA, Harris RR, Jarvis MF, Decker MW, Rueter LE. Behavioral profile of $\mathrm{P} 2 \mathrm{X} 7$ receptor knockout mice in animal models of depression and anxiety: relevance for neuropsychiatric disorders. Behav Brain Res. 2009; 198:83-90. https://doi.org/10.1016/j.bbr.2008.10.018.

77. Jørgensen NR, Husted LB, Skarratt KK, Stokes L, Tofteng CL, Kvist T, Jensen JE, Eiken P, Brixen K, Fuller S, CliftonBligh R, Gartland A, Schwarz P, et al. Single-nucleotide polymorphisms in the $\mathrm{P} 2 \mathrm{X} 7$ receptor gene are associated with post-menopausal bone loss and vertebral fractures. Eur J Hum Genet. 2012; 20:675-81. https://doi.org/10.1038/ ejhg.2011.253.

78. Adinolfi E, Raffaghello L, Giuliani AL, Cavazzini L, Capece M, Chiozzi P, Bianchi G, Kroemer G, Pistoia V, Di Virgilio F. Expression of $\mathrm{P} 2 \mathrm{X} 7$ receptor increases in vivo tumor growth. Cancer Res. 2012; 72:2957-69. https://doi. org/10.1158/0008-5472.CAN-11-1947.

79. Di Virgilio F, Ferrari D, Adinolfi E. P2X(7): a growthpromoting receptor-implications for cancer. Purinergic Signal. 2009; 5:251-56. https://doi.org/10.1007/s11302-009-9145-3.

80. Adinolfi E, Amoroso F, Giuliani AL. P2X7 receptor function in bone-related cancer. J Osteoporos. 2012; 2012:637863. https://doi.org/10.1155/2012/637863.

81. Amoroso F, Falzoni S, Adinolfi E, Ferrari D, Di Virgilio F. The $\mathrm{P} 2 \mathrm{X} 7$ receptor is a key modulator of aerobic glycolysis. Cell Death Dis. 2012; 3:e370. https://doi.org/10.1038/ cddis.2012.105.

82. Bartlett R, Yerbury JJ, Sluyter R. P2X7 receptor activation induces reactive oxygen species formation and cell death in murine EOC13 microglia. Mediators Inflamm. 2013; 2013:271813. https://doi.org/10.1155/2013/271813.

83. Gadeock S, Pupovac A, Sluyter V, Spildrejorde M, Sluyter R. P2X7 receptor activation mediates organic cation uptake into human myeloid leukaemic KG-1 cells. Purinergic Signal. 2012; 8:669-76. https://doi.org/10.1007/s11302012-9320-9.

84. Adinolfi E, Pizzirani C, Idzko M, Panther E, Norgauer J, Di Virgilio F, Ferrari D. P2X(7) receptor: death or life? Purinergic Signal. 2005; 1:219-27. https://doi.org/10.1007/ s11302-005-6322-x.

85. Tardivo JP, Del Giglio A, Paschoal LH, Ito AS, Baptista MS. Treatment of melanoma lesions using methylene blue and RL50 light source. Photodiagnosis Photodyn Ther. 2004; 1:345-6. https://doi.org/10.1016/S1572-1000(05)00005-0.

86. Schirmer RH, Adler H, Pickhardt M, Mandelkow E. Lest we forget you: methylene blue... Neurobiol Aging. 2011; 32. https://doi.org/10.1016/j.neurobiolaging.2010.12.012.

87. Liu X, Lee CC, Xu ZJ, Wen JS, Gu G, Ku W, Tranquada JM, Hill JP. X-ray diffuse scattering study of local distortions in Fe1+xTe induced by excess Fe. Phys Rev B Condens Matter Mater Phys. 2011; 83:184523. https://doi. org/10.1103/PhysRevB.83.184523.

88. Liu Y, Chen W, Wang S, Joly AG. Investigation of watersoluble $\mathrm{X}$-ray luminescence nanoparticles for photodynamic 
activation. Appl Phys Lett. AIP Publishing. 2008; 92:43901. https://doi.org/10.1063/1.2835701.

89. Kishwar S, Asif MH, Nur O, Willander M, Larsson PO. Intracellular $\mathrm{ZnO}$ Nanorods Conjugated with Protoporphyrin for Local Mediated Photochemistry and Efficient Treatment of Single Cancer Cell. Nanoscale Res Lett. 2010; 5:1669-74. https://doi.org/10.1007/s11671-0109693-z.

90. Scaffidi JP, Gregas MK, Lauly B, Zhang Y, Vo-Dinh T. Activity of psoralen-functionalized nanoscintillators against cancer cells upon X-ray excitation. ACS Nano. 2011; 5:4679-87. https://doi.org/10.1021/nn200511m.

91. Abliz E, Collins JE, Bell H, Tata DB. Novel applications of diagnostic $\mathrm{X}$-rays in activating a clinical photodynamic drug: Photofrin II through X-ray induced visible luminescence from "rare-earth" formulated particles. J Xray Sci Technol. 2011; 19:521-30. https://doi.org/10.3233/XST2011-0311.

92. Bulin AL, Truillet C, Chouikrat R, Lux F, Frochot C, Amans D, Ledoux G, Tillement O, Perriat P, Barberi-Heyob M, Dujardin C. X-ray-induced singlet oxygen activation with nanoscintillator-coupled porphyrins. J Phys Chem C. 2013; 117:21583-9. https://doi.org/10.1021/jp4077189.

93. Senthilkumar S, Hariharan R, Suganthi A, Ashokkumar M, Rajarajan M, Pitchumani K. Synergistic photodynamic action of $\mathrm{ZnO}$ nanomaterials encapsulated meso-tetra (4-sulfonatophenyl) porphyrin. Powder Technol. 2013; 237:497-505. https://doi.org/10.1016/j.powtec.2012.12.024.

94. Zou X, Yao M, Ma L, Hossu M, Han X, Juzenas P, Chen W. $\mathrm{X}$-ray-induced nanoparticle-based photodynamic therapy of cancer. Nanomedicine (Lond). 2014; 9:2339-51. https://doi. org/10.2217/nnm.13.198.

95. Homayoni H, Ma L, Zhang J, Sahi SK, Rashidi LH, Bui B, Chen W. Synthesis and conjugation of Sr2MgSi2O7:Eu2+, Dy3+ water soluble afterglow nanoparticles for photodynamic activation. Photodiagn Photodyn Ther. 2016; 16:90-99. https://doi.org/10.1016/j.pdpdt.2016.08.012.

96. Ma L, Zou X, Chen W. A new X-ray activated nanoparticle photosensitizer for cancer treatment. J Biomed Nanotechnol. 2014; 10:1501-08. https://doi.org/10.1166/jbn.2014.1954.

97. Ma L, Zou X, Hossu M, Chen W. Synthesis of ZnS:Ag,Co water-soluble blue afterglow nanoparticles and application in photodynamic activation. Nanotechnology. 2016; 27:315602. https://doi.org/10.1088/09574484/27/31/315602.

98. Chen H, Wang GD, Chuang YJ, Zhen Z, Chen X, Biddinger P, Hao Z, Liu F, Shen B, Pan Z, Xie J. Nanoscintillatormediated X-ray inducible photodynamic therapy for in vivo cancer treatment. Nano Lett. 2015; 15:2249-56. https://doi. org/10.1021/n1504044p.

99. Tang Y, Hu J, Elmenoufy AH, Yang X. Highly Efficient FRET System Capable of Deep Photodynamic Therapy Established on X-ray Excited Mesoporous LaF3:Tb Scintillating Nanoparticles. ACS Appl Mater Interfaces. 2015; 7:12261-9. https://doi.org/10.1021/acsami.5b03067.
100. Elmenoufy AH, Tang Y, Hu J, Xu H, Yang X. A novel deep photodynamic therapy modality combined with CT imaging established via X-ray stimulated silica-modified lanthanide scintillating nanoparticles. Chem Commun (Camb). 2015; 51:12247-50. https://doi.org/10.1039/C5CC04135J.

101. Clement S, Deng W, Camilleri E, Wilson BC, Goldys EM. $\mathrm{X}$-ray induced singlet oxygen generation by nanoparticlephotosensitizer conjugates for photodynamic therapy: determination of singlet oxygen quantum yield. Sci Rep. 2016; 6:19954. https://doi.org/10.1038/srep19954.

102. Zhang C, Zhao K, Bu W, Ni D, Liu Y, Feng J, Shi J. Marriage of scintillator and semiconductor for synchronous radiotherapy and deep photodynamic therapy with diminished oxygen dependence. Angew Chem Int Ed Engl. 2015; 54:1770-74. https://doi.org/10.1002/anie.201408472.

103. Rossi F, Bedogni E, Bigi F, Rimoldi T, Cristofolini L, Pinelli S, Alinovi R, Negri M, Dhanabalan SC, Attolini G, Fabbri F, Goldoni M, Mutti A, et al. Porphyrin conjugated SiC/ SiOx nanowires for X-ray-excited photodynamic therapy. Sci Rep. 2015; 5:7606. https://doi.org/10.1038/srep07606.

104. Generalov R, Kuan WB, Chen W, Kristensen S, Juzenas P. Radiosensitizing effect of zinc oxide and silica nanocomposites on cancer cells. Colloids Surf B Biointerfaces. 2015; 129:79-86. https://doi.org/10.1016/j. colsurfb.2015.03.026.

105. Kaščáková S, Giuliani A, Lacerda S, Pallier A, Mercère P, Tóth É, Réfrégiers M. X-ray-induced radiophotodynamic therapy (RPDT) using lanthanide micelles: beyond depth limitations. Nano Res. Tsinghua University Press. 2015; 8:2373-79. https://doi.org/10.1007/s12274-015-0747-5.

106. Samy NA, Salah MM, Ali MF, Sadek AM. Effect of methylene blue-mediated photodynamic therapy for treatment of basal cell carcinoma. Lasers Med Sci. 2015; 30:109-15. https://doi.org/10.1007/s10103-014-1609-1.

107. Schick E, Rück A, Boehncke WH, Kaufmann R. Topical photodynamic therapy using methylene blue and 5-aminolaevulinic acid in psoriasis. J Dermatolog Treat. 1997; 8:17-19. https://doi.org/10.3109/09546639709160503.

108. Aghahosseini F, Arbabi-Kalati F, Fashtami LA, Fateh M, Djavid GE. Treatment of oral lichen planus with photodynamic therapy mediated methylene blue: a case report. Med Oral Patol Oral Cir Bucal. 2006; 11:E126-29.

109. Salah M, Samy N, Fadel M. Methylene blue mediated photodynamic therapy for resistant plaque psoriasis. J Drugs Dermatol. 2009; 8:42-49. http://www.ncbi.nlm.nih. gov/pubmed/19180895.

110. Figueiredo Souza LW, Souza SV, Botelho AC. Randomized controlled trial comparing photodynamic therapy based on methylene blue dye and fluconazole for toenail onychomycosis. Dermatol Ther (Heidelb). 2014; 27:43-47. https://doi.org/10.1111/dth.12042.

111. Fadel M, Salah M, Samy N, Mona S. Liposomal methylene blue hydrogel for selective photodynamic therapy of acne vulgaris. J Drugs Dermatol. 2009; 8:983-90. http://www. ncbi.nlm.nih.gov/pubmed/19894365. 
112. Tardivo JP, Adami F, Correa JA, Pinhal MA, Baptista MS. A clinical trial testing the efficacy of PDT in preventing amputation in diabetic patients. Photodiagn Photodyn Ther. 2014; 11:342-50. https://doi.org/10.1016/j. pdpdt.2014.04.007.

113. Noro Filho GA, Casarin RC, Casati MZ, Giovani EM. PDT in non-surgical treatment of periodontitis in HIV patients: A split-mouth, randomized clinical trial. Lasers Surg Med. 2012; 44:296-302. https://doi.org/10.1002/ lsm. 22016 .

114. Slater M, Danieletto S, Gidley-Baird A, Teh LC, Barden JA. Early prostate cancer detected using expression of non-functional cytolytic P2X7 receptors. Histopathology. 2004; 44:206-15. https://doi.org/10.1111/j.03090167.2004.01798.x.

115. Jelassi B, Anchelin M, Chamouton J, Cayuela ML, Clarysse L, Li J. Goré J, Jiang LH, Roger S. Anthraquinone emodin inhibits human cancer cell invasiveness by antagonizing P2X7 receptors. Carcinogenesis. 2013; 34:1487-96. https:// doi.org/10.1093/carcin/bgt099.

116. Solini A, Cuccato S, Ferrari D, Santini E, Gulinelli S, Callegari MG, Dardano A, Faviana P, Madec S, Di Virgilio F, Monzani F. Increased P2X7 receptor expression and function in thyroid papillary cancer: a new potential marker of the disease? Endocrinology. 2008; 149:389-96. https:// doi.org/10.1210/en.2007-1223.

117. Künzli BM, Berberat PO, Giese T, Csizmadia E, Kaczmarek E, Baker C, Halaceli I, Büchler MW, Friess H, Robson SC. Upregulation of CD39/NTPDases and P2 receptors in human pancreatic disease. Am J Physiol Gastrointest Liver Physiol. 2007; 292:G223-30. https://doi.org/10.1152/ ajpgi.00259.2006.

118. Li X, Zhou L, Feng YH, Abdul-Karim FW, Gorodeski GI. The P2X7 receptor: a novel biomarker of uterine epithelial cancers. Cancer Epidemiol Biomarkers Prev. 2006; 15:1906-13. https://doi.org/10.1158/1055-9965.EPI-060407.

119. Raffaghello L, Chiozzi P, Falzoni S, Di Virgilio F, Pistoia V. The P2X7 receptor sustains the growth of human neuroblastoma cells through a substance P-dependent mechanism. Cancer Res. 2006; 66:907-14. https://doi. org/10.1158/0008-5472.CAN-05-3185.
120. White N, Knight GE, Butler PE, Burnstock G. An in vivo model of melanoma: treatment with ATP. Purinergic Signal. 2009; 5:327-33. https://doi.org/10.1007/s11302-009-9156-0.

121. Adinolfi E, Melchiorri L, Falzoni S, Chiozzi P, Morelli A, Tieghi A, Cuneo A, Castoldi G, Di Virgilio F, Baricordi OR. $\mathrm{P} 2 \mathrm{X} 7$ receptor expression in evolutive and indolent forms of chronic B lymphocytic leukemia. Blood. 2002; 99:70608. https://doi.org/10.1182/blood.V99.2.706.

122. Liu H, Liu W, Liu Z, Liu Y, Zhang W, Xu L, Xu J. Prognostic value of purinergic P2X7 receptor expression in patients with hepatocellular carcinoma after curative resection. Tumour Biol. 2015; 36:5039-49. https://doi. org/10.1007/s13277-015-3155-2.

123. Vázquez-Cuevas FG, Martínez-Ramírez AS, RoblesMartínez L, Garay E, García-Carrancá A, Pérez-Montiel D, Castañeda-García C, Arellano RO. Paracrine stimulation of $\mathrm{P} 2 \mathrm{X} 7$ receptor by ATP activates a proliferative pathway in ovarian carcinoma cells. J Cell Biochem. 2014; 115:195566. https://doi.org/10.1002/jcb.24867.

124. Gu LQ, Li FY, Zhao L, Liu Y, Chu Q, Zang XX, Liu JM, Ning G, Zhao YJ. Association of XIAP and P2X7 receptor expression with lymph node metastasis in papillary thyroid carcinoma. Endocrine. 2010; 38:276-82. https://doi. org/10.1007/s12020-010-9384-7.

125. Takai E, Tsukimoto M, Harada H, Sawada K, Moriyama Y, Kojima S. Autocrine regulation of TGF- $\beta 1$-induced cell migration by exocytosis of ATP and activation of P2 receptors in human lung cancer cells. J Cell Sci. 2012; 125:5051-60. https://doi.org/10.1242/jcs.104976.

126. Gehring MP, Pereira TC, Zanin RF, Borges MC, Braga Filho A, Battastini AM, Bogo MR, Lenz G, Campos MM, Morrone FB. P2X7 receptor activation leads to increased cell death in a radiosensitive human glioma cell line. Purinergic Signal. 2012; 8:729-39. https://doi.org/10.1007/ s11302-012-9319-2.

127. Bian S, Sun X, Bai A, Zhang C, Li L, Enjyoji K, Junger WG, Robson SC, Wu Y. P2X7 Integrates PI3K/AKT and AMPKPRAS40-mTOR Signaling Pathways to Mediate Tumor Cell Death. Kanellopoulos J, editor. PLoS One. 2013; 8:e60184. https://doi.org/10.1371/journal.pone.0060184. 